\title{
Proposta de aumento da capacidade de tratamento e melhoria da qualidade do efluente da ETE de Campina Grande-PB usando a combinação UASB e lagoas de polimento
}

\section{Proposal for increasing the treatment capacity and improving the quality of the effluent of Campina Grande's WWTP using the combination of UASB and polishing ponds}

Data de entrada: 02/06/2019

Data de aprovação: $18 / 06 / 2020$
Adrianus van Haandel ${ }^{1 * *}$ | Silvânia Lucas dos Santos ${ }^{2}$

ORCID ID

Haandel A (D) https://orcid.org/0000-0002-9937-6715
DOI: https://doi.org/10.36659/dae.2021.026

Santos SL (D) https://orcid.org/0000-0002-6905-3966

\section{Resumo}

Nos artigos anteriores desta série, mostrou-se que sistemas de lagoas de estabilização (LE) apresentam desvantagens que podem ser reduzidas ou mesmo eliminadas quando se substitui a configuração convencional (lagoa anaeróbia/lagoa facultativa/lagoas de maturação) por um sistema composto de um reator UASB seguido por Lagoas de polimento (LP). Essa substituição possibilita o aumento da capacidade de tratamento, melhora a qualidade do efluente, reduz o tamanho e consequentemente os custos de construção, além de permitir a captura do biogás e o aproveitamento do lodo como biofertilizante. Como exemplo, analisaram-se as vantagens de aplicar o reator UASB seguido de LP em substituição ao sistema convencional de LE que se encontra em operação na cidade de Campina Grande, Paraíba. A atual ETE de Campina Grande é constituída por duas lagoas anaeróbias, duas lagoas facultativas e quatro lagoas de maturação, com capacidade para tratar 13.000 $\mathrm{m}^{3} / \mathrm{d}$. A análise mostrou que todas as vantagens do novo sistema podem ser materializadas no caso de Campina Grande. Quando se substitui o sistema convencional pela nova alternativa, a capacidade de tratamento da ETE, com a infraestrutura existente, aumentaria para $40.000 \mathrm{~m}^{3} / \mathrm{d}$ se o efluente fosse utilizado para fertirrigação ou $20.000 \mathrm{~m}^{3} / \mathrm{d}$ se o efluente fosse utilizado para fins industriais; nesse caso, a remoção de nutrientes é necessária. Assim, todo o efluente seria utilizado de maneira produtiva e não haveria mais descarga nas águas de superfície. Palavras-chave: Lagoas de polimento. Reúso agrícola. Reúso industrial. Custo construção.

\section{Abstract}

In the previous articles of this series, it has been shown that stabilization pond (LE) systems have disadvantages that can be reduced or even eliminated when the conventional configuration (anaerobic pond/optional pond/maturation ponds) is replaced by a system composed of a UASB reactor followed by polishing ponds (LP). This substitution makes it possible to increase the treatment capacity, improve the quality of the effluent, reduce the size and consequently the construction costs, in addition to allowing capture of biogas and the use of sludge as a biofertilizer. As

\footnotetext{
${ }^{1}$ Universidade Federal de Campina Grande - UFCG - Campina Grande - Paraíba - Brasil.

2 Universidade Federal do Rio Grande do Norte - UFRN - Natal - Rio Grande do Norte - Brasil.

* Autor correspondente: adrianusvhagmail.com.
} 
an example, we analyzed the advantages of applying the UASB reactor followed by LP to replace the conventional LE system that is in operation in the city of Campina Grande, Paraiba. The current WWTP in Campina Grande consists of two anaerobic lagoons, two optional lagoons and four maturation lagoons, with a capacity to treat $13,000 \mathrm{~m}^{3} / \mathrm{d}$. The analysis showed that all the advantages of the new system can be materialized in the case of Campina Grande. When the conventional system is replaced by the new alternative, the treatment capacity of the WWTP, with the existing infrastructure, would increase to $40,000 \mathrm{~m}^{3} / \mathrm{d}$ if the effluent was used for fertigation or $20,000 \mathrm{~m}^{3} / \mathrm{d}$ if the effluent was used for industrial purposes; in this case, the removal of nutrients is necessary. Thus, all the effluent would be used productively and there would be no more discharge into surface waters.

Keywords: Polishing ponds. Agricultural reuse. Industrial reuse. Construction cost.

\section{INTRODUÇÃO}

A cidade de Campina Grande, na Paraíba, por estar localizada no semiárido brasileiro, enfrenta costumeiramente problemas decorrentes da escassez de recursos hídricos. Para eliminar esse problema, uma alternativa potencial é o aproveitamento racional do esgoto municipal gerado na área urbana. Embora a rede de coleta atenda a mais de $90 \%$ da população urbana, parte do esgoto produzido ainda é lançada diretamente, sem tratamento prévio, no meio ambiente, atingindo os corpos d'água. A parcela de esgoto tratado é encaminhado à Estação de Tratamento de Esgoto (ETE), que emprega o sistema de lagoas de estabilização (lagoas anaeróbia, facultativa e maturação); tratamento este que atua na remoção do material orgânico e patógenos, sendo pouco eficiente na remoção de nutrientes, o que resulta em problemas de eutrofização no corpo receptor. Diante dos problemas ambientais causados pelo lançamento inadequado do esgoto, bem como da necessidade de uma fonte adicional de água para suprir as demandas hídricas existentes (agrícola, urbano, industrial), o esgoto municipal, caso tratado de forma adequada, constitui uma alternativa interessante. Nesse sentido, o objetivo do presente artigo é demonstrar um caminho para transformar esse passivo em um ativo ambiental, tornando o esgoto uma nova fonte de água com características adequadas para ser usada na indústria, na agricultura ou, ainda, na proteção do corpo receptor do efluente da ETE.
Uma análise da situação atual leva à conclusão de que a vazão de esgoto que chega à ETE corresponde a apenas $1 / 3$ da vazão de esgoto gerada na cidade. Sendo assim, a capacidade de tratamento do sistema é superior à vazão afluente, devido à perda que ocorre ao longo da rede coletora. Nessa situação, o sistema de tratamento consegue obter uma remoção bastante eficiente do material orgânico (DBO), mas geralmente ainda apresenta concentrações de patógenos, em especial as bactérias do grupo coliformes, acima do limite estabelecido para lançamento pela Resolução Conama $n^{\circ} 430 / 2011$, que é de $10^{3} \mathrm{org} / 100 \mathrm{~mL}$. Caso a ETE estivesse funcionando na sua capacidade de projeto, esse efluente dificilmente seria adequado à irrigação de culturas.

Estudos desenvolvidos e apresentados nesta série levaram ao desenvolvimento de um novo sistema de tratamento de esgoto que pode ser utilizado em Campina Grande, transformando o sistema de tratamento de esgoto existente em uma "fábrica" de água nova a ser usada para diversas aplicações. O sistema é composto basicamente de um pré-tratamento anaeróbio eficiente (reator UASB) e um pós-tratamento em lagoas de polimento de bateladas sequenciais. Dependendo das condições de operação das lagoas de polimento, o efluente tratado pode apresentar característica adequada para diversos fins: (1) reúso agrícola para irrigação sem restrições, removendo material orgânico, ovos de helmintos e bactérias do grupo 
Coliformes, mas mantendo os nutrientes; (2) reúso industrial, removendo, além de material orgânico e patógenos, nutrientes (nitrogênio e fósforo) e sólidos suspensos ou; (3) descarga em águas de superfície, removendo material orgânico, patógenos e nutrientes para proteção do corpo receptor.

A adoção do novo sistema de tratamento aumentaria a capacidade de tratamento para $40.000 \mathrm{~m}^{3} / \mathrm{d}$, caso o objetivo fosse a produção de água para a agricultura, ou para $20.000 \mathrm{~m}^{3} / \mathrm{d}$, caso o objetivo fosse a produção de água para o reúso industrial, mantendo basicamente a infraestrutura que já existe. Já para produzir concomitantemente $10.000 \mathrm{~m}^{3} / \mathrm{d}$ de água para indústrias e $30.000 \mathrm{~m}^{3} . \mathrm{d}^{-1}$ de água para agricultura haveria necessidade de ampliar as seis lagoas de maturação/polimento existentes, com a adição de mais três unidades. Desta forma, todo o esgoto de Campina Grande poderia se tornar uma fonte de água para uso produtivo dentro e no entorno da área urbana, sem a necessidade de haver descarga de efluente no corpo d'água receptor e, consequentemente, cessariam os problemas ambientais relacionados ao lançamento do efluente.

\section{RECURSOS HÍDRICOS NA REGIÃO DO MÉDIO PARAÍBA}

O município de Campina Grande, localizado no estado da Paraíba, tem uma população total de aproximadamente 400.000 habitantes (IBGE, 2020), o que faz dele um dos maiores municípios do interior do Nordeste. A cidade, também conhecida como a Rainha da Borborema, situa-se a uma distância de 120 km da capital João Pessoa. Como não há na região recursos hídricos perenes, Campina Grande e outros municípios do entorno são abastecidos com a água acumulada no Açude Epitácio Pessoa, também conhecido como “Açude Boqueirão". A capacidade de armazenamento do açude é de aproximadamente 466 milhões de $\mathrm{m}^{3}$ (AESA, 2020). A água do reservatório provém de duas sub-bacias hidrográficas: bacia do Rio Paraíba e bacia do Rio
Taperoá, que juntas têm uma vazão média de 4.000 L/s (AESA, 2006), enquanto a demanda média de abastecimento é de aproximadamente $2.000 \mathrm{~L} / \mathrm{s}$. Embora a vazão média dos rios seja maior do que a demanda de água tratada, nos últimos anos tem ocorrido vários e prolongados períodos de racionamento de água. A razão principal da incerteza hídrica é a irregularidade das chuvas no Nordeste, além de outras demandas existentes no reservatório. Recentemente, foi concluída a transposição das águas do Rio São Francisco, que no futuro poderá amenizar a falta de água crônica na região do médio Paraíba, embora os primeiros anos de operação não tenham sido animadores.

Em Campina Grande, um elevado percentual (>90\%) da população urbana é atendida pela rede coletora esgoto (SNIS, 2020). O esgoto coletado é tratado em sua maioria numa ETE central, localizada no bairro da Caatingueira e depois é descarregado no Riacho Bodocongó, de onde escoa por gravidade para o Açude de Acauã que tem uma capacidade de armazenamento de 250 milhões de $\mathrm{m}^{3}$. O Açude Argemiro de Figueiredo, ou Acauã, é extensivamente usado para o abastecimento de municípios vizinhos, apesar de apresentar problemas de qualidade da água, como a eutrofização, devido ao aporte de nutrientes, principalmente decorrente do lançamento do esgoto de Campina Grande (LINS, 2006; 2011). A Fig. 1 mostra a área do médio Paraíba com os pontos críticos: (1) captação no Açude Boqueirão, (2) tratamento de água na ETA Gravatá, (3) transporte da água tratada, (4) distribuição de água em Campina Grande e cidades vizinhas, (5) uso da água, (6) coleta de esgoto, (7) transporte do esgoto bruto até a ETE da Caatingueira, (8) tratamento de esgoto e (9) descarga do efluente no Riacho Bodocongó.

A água captada no açude Epitácio Pessoa é recalcada para a estação de tratamento de água (ETA) de Gravatá, distante uns $5 \mathrm{~km}$ do ponto de captação, e após o tratamento convencional a água é transportada para reservatórios na cidade de 
Campina Grande e outros na região. Esses reservatórios estão instalados em pontos altos do terreno acidentado, de modo que a distribuição da água de abastecimento possa ser feita por gravidade. Depois do uso da água pela população e pelas indústrias, a água é descartada na rede de coleta como água residuária ou esgoto que, por sua vez, é transportada até uma estação de tratamento de esgoto (ETE). Em Campina Grande, praticamente todo o esgoto coletado pode escoar por gravidade até a ETE, sem a necessidade de estações elevatórias (EE). Depois do tratamento, o efluente final é descarregado no Riacho Bodocongó, que corta a cidade. O riacho é tributário do Rio Paraíba que, por sua vez, descarrega no Açude Acauã. Na Fig. 2 , podem-se observar esquematicamente os processos que são necessários para abastecer a cidade com água e esgotar a água residuária.

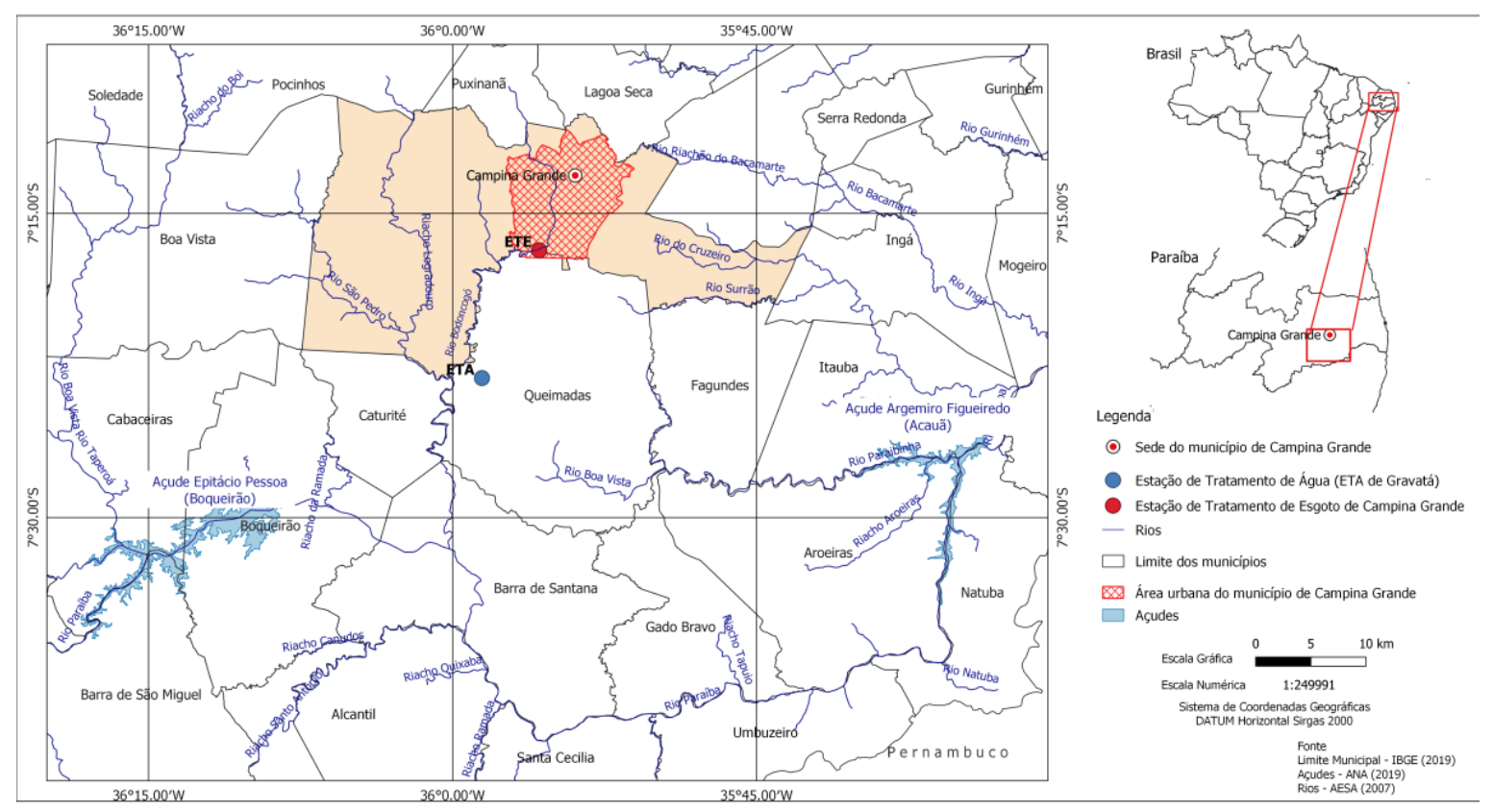

Figura 1 - Situação de estruturas de recursos hídricos no Médio Paraíba. Fonte: Autor, 2020

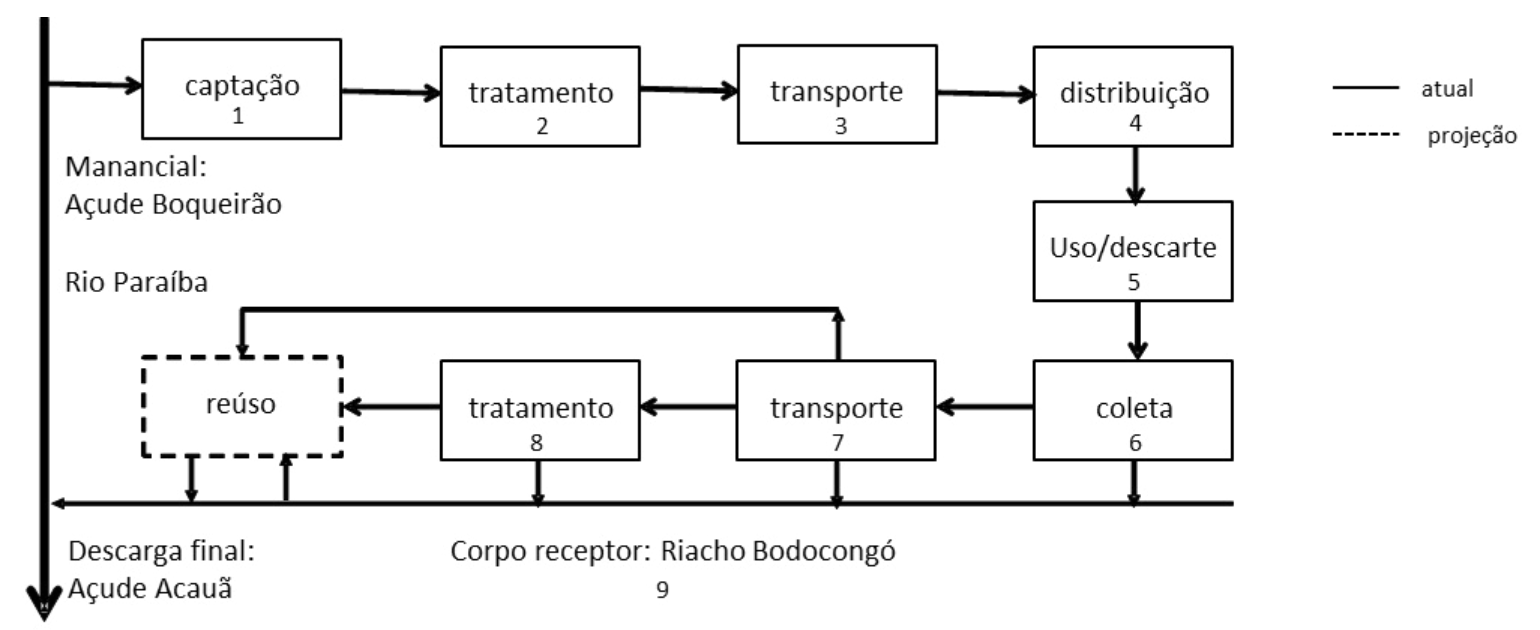

Figura 2 - Representação esquemática dos processos de abastecimento de água, coleta e tratamento de esgoto na cidade de Campina Grande. 
A destinação final de esgoto em Campina Grande, na prática, apresenta vários problemas:

(1) Falta de adesão à rede coletora. Nem todas as economias ligadas à rede coletora efetivamente fazem a ligação, podendo preferir soluções preexistentes, como fossa séptica, e o esgoto acaba infiltrando no solo, ou ligar-se à rede de drenagem de águas pluviais, em que o esgoto acaba sendo descarregado no Riacho Bodocongó;

(2) Perdas de esgoto ao longo do sistema de coleta, seja por obstruções na rede ou desvios da água para irrigação;
(3) Uso extensivo do esgoto, bruto ou parcialmente tratado, para irrigação de diferentes culturas, a exemplo de capim e verduras (GOMES, 2013).

\section{PROBLEMAS DE SANEAMENTO BÁSICO NO MÉDIO PARAÍBA}

Na Fig. 3, é possível observar os problemas de abastecimento de água e destinação final de esgoto na cidade de Campina Grande.

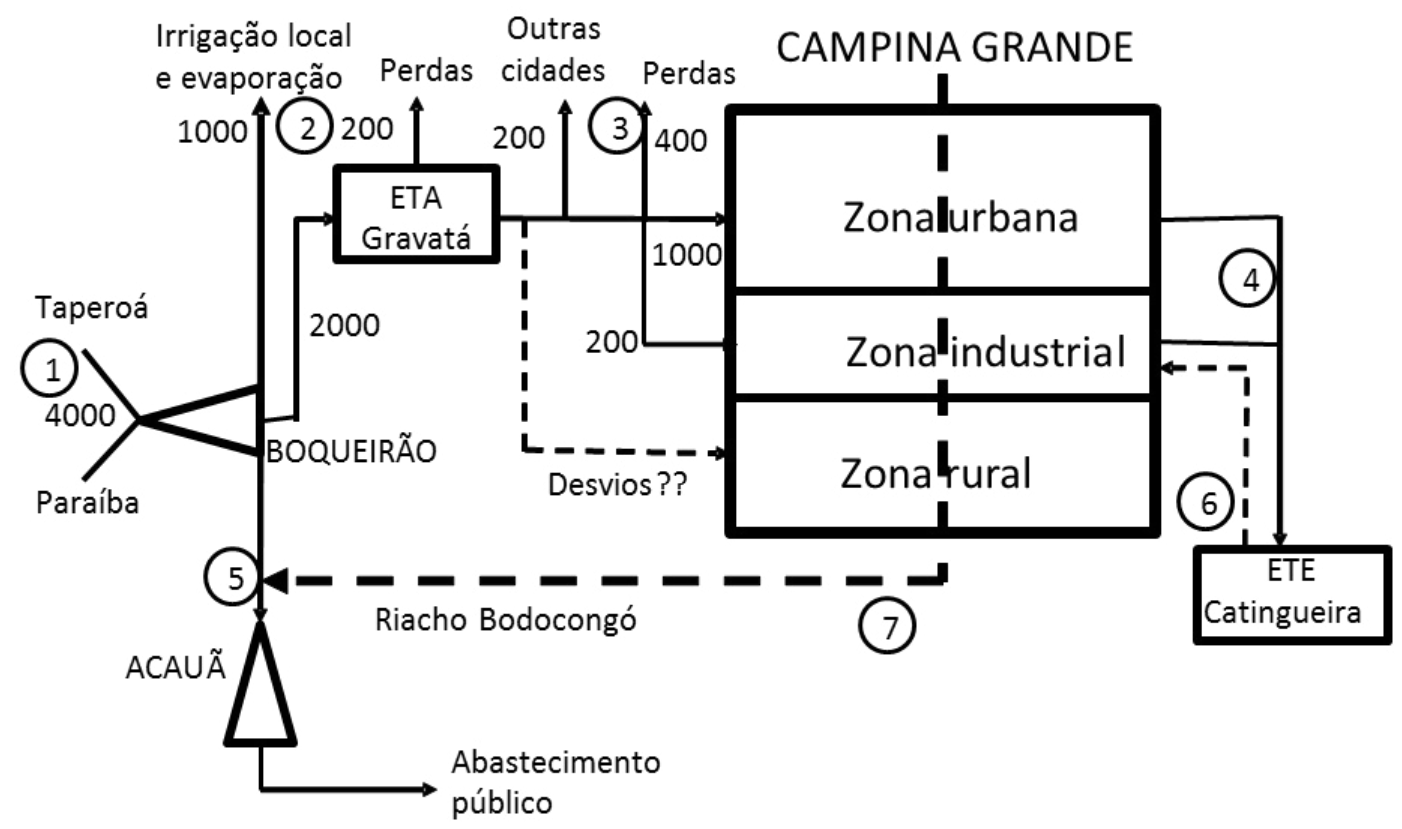

Figura 3 - Os sete principais problemas do uso de recursos hídricos e saneamento básico em Campina Grande (valores numéricos: vazão aproximada em L/s).

\section{(A) Problemas de abastecimento de água}

(1) Açudes a montante de Boqueirão armazenam e usam água para diversos fins

Diversas propriedades rurais situadas às margens dos rios Paraíba e Taperoá construíram alguma estrutura de armazenamento de água para irrigação local e dessedentação de animais. Ain- da que esse uso individualmente seja pequeno, o total de usuários desvia uma quantidade considerável de água que de outra maneira estaria disponível para abastecimento. A construção das estruturas de armazenamento desse tipo não é legal, sendo, portanto, necessária uma fiscalização mais atuante na região. 
(2) Evaporação e perdas no tratamento e transporte

O Açude Boqueirão tem uma área superficial elevada $\left(40 \mathrm{~km}^{2}\right)$ e, por isso, as perdas por evaporação são bastante significativas: para uma taxa de evaporação média de $2,5 \mathrm{~mm} / \mathrm{d}$ de água, a perda fica em torno de $1.000 \mathrm{~L} / \mathrm{s}$, que é da mesma ordem de grandeza da demanda de água para abastecimento de Campina Grande, que também fica em torno de 1.000L/s (ANA, 2020). Por outro lado, as perdas de água no sistema de tratamento de água da cidade é $10 \%$ da vazão processada, o que é muito maior do que o valor comumente apresentado em sistemas de tratamento convencional (coagulação, floculação, sedimentação e filtração de alta taxa) aplicados em Campina Grande. Não se sabe a magnitude dos desvios que ocorrem ao longo do transporte da água tratada da ETA para os reservatórios de abastecimento.

\section{(3) Perda na distribuição}

Uma fonte importante de perdas de água é a rede de distribuição: em torno de $40 \%$ da água tratada que é transportada para as cidades não é efetivamente vendida. Os desvios se dão de várias maneiras: vazamento na rede de distribuição, desvios de volumes maiores para fins agrícolas e desvios de volumes menores nas ligações residenciais, onde muitos usuários têm uma segunda entrada de água que é "informal".

\section{(B) Problemas de coleta, transporte e tratamento de esgoto}

(4) Perdas na coleta de esgoto

Grande parte do esgoto gerado na cidade de Campina Grande não chega até a estação de tratamento porque, por diversas razões, o esgoto bruto é desviado. Em parte, esse desvio se inicia logo na origem do esgoto: residências com sistemas tradicionais, como a fossa séptica, insta- lados antes da construção da rede de coleta de esgoto não fizeram a ligação à rede e o efluente dessas fossas, em grande parte, termina fluindo para o Riacho Bodocongó, que atravessa grande parte da cidade ou é absorvida pela rede de drenagem pluvial. Outra perda grande de esgoto é causada pelos entupimentos contínuos da rede de esgoto: o esgoto acaba extravasando e atingindo a rede de drenagem pluvial. Esses dois fatores causam, juntos, uma perda de mais de $67 \%$ do esgoto gerado em Campina Grande, sendo que grande parte acaba sendo descarregada no Riacho Bodocongó. Como consequência, o Riacho (que era intermitente antes da construção das redes de esgoto de água pluvial) hoje é um riacho perene.

\section{(5) Combate à eutrofização do açude Acauã}

O Riacho Bodocongó recebe tanto o esgoto sanitário bruto como o esgoto tratado, e essas águas acabam sendo descarregadas no Açude Acauã, que fica a uma distância de $100 \mathrm{~km}$ aproximadamente. $O$ tempo de permanência dos esgotos parcialmente tratados até sua descarga no Açude Acauã é suficiente para remover grande parte do material orgânico e dos organismos patogênicos, mas a remoção dos nutrientes é ineficiente, de modo que grande parte aflui para o reservatório, contribuindo de maneira decisiva para a eutrofização, prejudicando a população da região que é abastecida com a água do açude. $A$ proliferação de algas no Açude Acauã dificulta o tratamento realizado pela Companhia de Abastecimento de Água e Esgoto, que deve distribuir uma água de boa qualidade, quanto aos parâmetros físicos, químicos e biológicos.

\section{(6) Falha no reúso para indústria}

Campina Grande está sendo prejudicada há décadas pela falta de água. Notadamente, o setor industrial hesita em iniciar desenvolvimentos 
de porte na região. No entanto, a solução desse problema pode estar na própria cidade. É perfeitamente possível coletar o esgoto e produzir um efluente de qualidade aceitável para as indústrias. Tal atividade teria várias vantagens importantes:

(a) A cidade teria água em quantidade e qualidade para as indústrias e, com isso, um dos mais importantes entraves do desenvolvimento industrial seria solucionado;

(b) Ao mesmo tempo, haveria uma redução da demanda de água do Açude Boqueirão, uma vez que a indústria não mais iria competir com o abastecimento público;

(c) O problema de eutrofização da água do açude Acauã seria resolvido, uma vez que a descarga de nutrientes no açude seria em grande parte evitada.

\section{(7) Falha do reúso na agricultura}

Alternativamente, o efluente do sistema de tratamento de esgoto poderia ser usado na agricultura. Nesse caso, o tratamento de esgoto seria mais simples, uma vez que a remoção de nutrientes não seria necessária e poderia ser contraprodutiva. Todavia, se existe a possibilidade de reúso industrial, é vantagem aplicar essa opção, uma vez que a água na indústria vale mais e as indústrias estão dispostas (e acostumadas!) a pagar um preço justo pela água. Naturalmente, é possível tratar parte do esgoto para produzir água para suprir a demanda das indústrias (com custo e preço mais elevados) e o restante para uso na agricultura (com custo e preço moderados).

Considerando os pontos mencionados acima, pode-se resumir os problemas associados aos recursos hídricos como se segue:
(1) A disponibilidade de água na Paraíba é limitada, embora no futuro próximo possa aumentar com a efetivação da transposição de águas do Rio São Francisco. De toda maneira, é previsível prever que haverá uma competição dos usuários nos diferentes estados pelos parcos recursos hídricos e seus múltiplos usos;

(2) Mesmo sendo de conhecimento público que a falta de água causa graves transtornos para a população e que essa falta talvez seja uma das maiores causas do lento progresso econômico da região Nordeste, tanto qualitativa como quantitativamente, não se consegue evitar enormes perdas devido a evaporação, perdas na distribuição e desvios.

(3) Há armazenamento indevido em grande escala na região dos rios Taperoá e Paraíba antes da formação do açude Epitácio Pessoa para uso particular em atividades ligadas à agricultura e à pecuária. Isso mostra a precária fiscalização na região.

(4) A falta de modernização no tratamento e na distribuição de água leva a grandes e injustificáveis perdas de água tratada.

(5) Embora enormes investimentos tenham sido feitos para a construção de uma rede de esgoto, somente uma pequena parte do esgoto gerado na cidade de Campina Grande chega efetivamente à estação de tratamento de esgoto; de longe a maior parte é desviada para a rede de drenagem pluvial e segue para o açude Acauã sem tratamento algum.

(6) Como consequência das descargas indevidas de esgoto no Riacho Bodocongó, sua água é de baixa qualidade higiênica. Ainda assim, vem sendo utilizada amplamente para atividades agrícolas, incluindo a produção de capim e hortaliças. 
(7) 0 tratamento disponível na ETE de Campina Grande não permite a remoção de nutrientes, de modo que, mesmo se todo o esgoto fosse tratado no sistema de lagoas de estabilização, os nutrientes continuariam chegando ao açude Acauã, prejudicando a qualidade de sua água pela eutrofização.

(8) Ainda que historicamente se tenham perdido várias oportunidades de um desenvolvimento industrial mais robusto em Campina Grande e mesmo sabendo que existem processos bem conhecidos para a transformação de esgoto em água adequada para aplicações na indústria, as autoridades não desenvolvem estratégias para que o reúso industrial se torne uma realidade nos próximos anos. Como consequência, o desenvolvimento industrial se manterá precário, ainda que as possibilidades de uma renovação da atividade industrial existam.

\section{SISTEMA DE TRATAMENTO DE ESGOTO EXISTENTE EM CAMPINA GRANDE}

O sistema de tratamento de esgoto de Campina Grande se situa no bairro da Caatingueira e recebe esgoto (por gravidade) proveniente das duas principais subbacias de esgotamento da cidade: bacia da Depuradora e Bacia do Bodocongó. A ETE fica às margens do riacho Bodocongó, o qual funciona como corpo receptor do efluente tratado. A Fig. 4 é uma representação esquemática da ETE de Campina Grande. O sistema começou a ser construído nos anos 70 e inicialmente se compôs de uma caixa de areia e duas lagoas aeradas com uma área de 1,5 ha cada e uma profundidade de $4 \mathrm{~m}$. Com o tempo, os aeradores mecânicos quebraram e as lagoas passaram a operar como lagoas anaeróbias, o que resultou surpreendentemente em um aumento da eficiência de remoção da DBO.

Um grande problema do esgoto sempre foi a presença de sólidos inorgânicos em suspensão, especialmente depois das fortes chuvas, e esses sólidos não podiam ser retidos pela estrutura da caixa de areia, que era muito pequena. Por essa razão, foi construída uma estrutura maior e mecanizada a fim de aumentar a eficiência de retenção de areia e assim aliviar o problema de acumulação de sólidos nas lagoas que tem causado repetidamente assoreamento.

Posteriormente, o sistema de tratamento precisou ser ampliado devido ao crescimento urbano. Um novo sistema foi construído, sendo iniciado em 2013. A ETE considera as unidades anteriormente construídas (caixa de areia com grade mecanizada, calha Parshall e duas lagoas anaeróbias), onde o esgoto é inicialmente tratado e, então, recalcado para as unidades recentemente instaladas. A nova estrutura, denominada ETE da Caiçara, é constituída de um sistema de lagoas de estabilização de fluxo contínuo composto por dois módulos, sendo que cada módulo possui uma lagoa facultativa e duas de maturação que operam em série. Um terceiro módulo está previsto para operar em etapas posteriores. A vazão total de projeto é de $644 \mathrm{~L} / \mathrm{s}$ (CAMPINA GRANDE, 2015). A área total das lagoas em funcionamento ( 2 módulos) é de 24 hectares, aproximadamente, para remoção adicional de material orgânico e patógeno. O efluente final continua sendo descarregado no Riacho Bodocongó. 


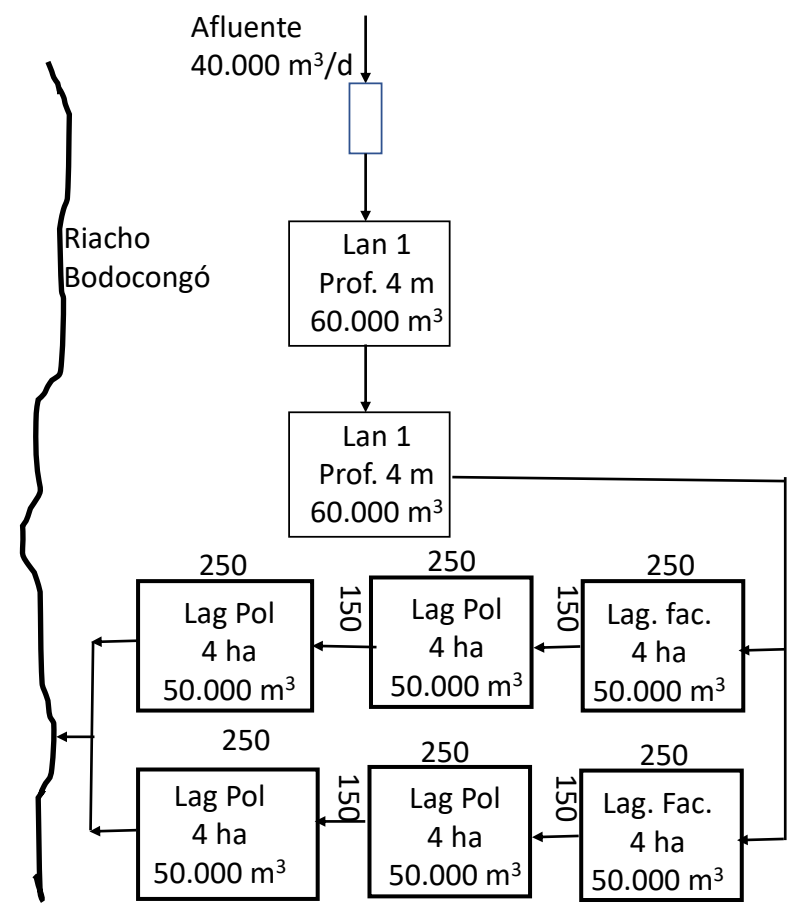

Figura 4 - Projeto do fluxograma do sistema de tratamento de esgoto de Campina Grande PB (sem escala).

\subsection{Problemas do sistema atual de tratamento}

Na Tabela 1, pode-se observar a caracterização do esgoto municipal e os valores das dimensões das unidades de tratamento do sistema existente. Para efeito de cálculos, estimou-se uma contribuição per capita de 100 L.hab-1. A DQQO do es- goto é na faixa de $0,8 \mathrm{~g} \cdot \mathrm{L}^{-1}$, o que representa uma contribuição de $80 \mathrm{gDO} O \cdot \mathrm{hab}^{-1} \cdot \mathrm{d}^{-1}$.

Dos vários problemas que assolam o sistema de tratamento de esgoto atualmente, os mais importantes são:

Tabela 1 - Valores das características do esgoto e da ETE de Campina Grande e dimensões das unidades de tratamento existentes na ETE.

\begin{tabular}{|c|c|c|c|c|c|}
\hline \multicolumn{3}{|c|}{ Esgoto de Campina Grande } & \multicolumn{3}{|c|}{ Infraestrutura da ETE } \\
\hline Variáveis & Valores & Unidades & Sistema & Variáveis & Valores \\
\hline População & 400.000 & -1 & Etapa 1 & & \\
\hline Per capita esgoto & 100 & 1 & \multirow{4}{*}{$\begin{array}{l}\text { Lagoa } 1 \\
\text { e } \\
\text { Lagoa } 2\end{array}$} & Profundidade & $4 \mathrm{~m}$ \\
\hline Per capita DQQO & 80 & 1 & & Área & $1,5 \mathrm{ha}$ \\
\hline Per capita N & 10 & -1 & & Volume & $60.000 \mathrm{~m}^{3}$ \\
\hline Per capita P & 2 & 0 & & & \\
\hline Composição & & & Etapa 2 & & \\
\hline Vazão de esgoto & 40.000 & $\mathrm{~m}^{3} / \mathrm{d}$ & \multirow{10}{*}{$\begin{array}{l}\text { Lagoas de polimento } \\
1 \text { a } 6 \\
\text { (média) }\end{array}$} & Profundidade & $1,25 \mathrm{~m}$ \\
\hline Vazão tratada & 13.000 & $\mathrm{~m}^{3} / \mathrm{d}$ & & Comprimento & $250 \mathrm{~m}$ \\
\hline $\mathrm{DQO}^{1}$ & 0,8 & $\mathrm{~g} / \mathrm{L}$ & & Largura & $150 \mathrm{~m}$ \\
\hline $\mathrm{STS}^{2}$ & 0,3 & $g / L$ & & Área & $33.000 \mathrm{~m}^{2}$ \\
\hline $\mathrm{NTK}^{3}$ & 0,08 & $g / L$ & & Volume & $50.000 \mathrm{~m}^{3}$ \\
\hline P tot & 0,01 & $g / L$ & & & \\
\hline Alcalinidade & 8 & meq/L & & & \\
\hline $\mathrm{pH}$ & 7,2 & - & & & \\
\hline $\mathrm{CTT}^{4}$ & $10^{7}$ & $/ 100 \mathrm{~mL}$ & & & \\
\hline Ovos helmintos & 100 & $/ \mathrm{L}$ & & & \\
\hline
\end{tabular}

'Demanda química de oxigênio; ${ }^{2}$ Sólidos Suspensos Totais; ${ }^{3}$ Nitrogênio Total Kjeldahl; 4Coliformes Termotolerantes 
(1) Devido a crônicos problemas de entupimentos da rede de coleta de esgoto, somente uma parte do esgoto gerado na cidade é realmente transportada para a ETE da Caatingueira. A vazão tratada é de aproximadamente $150 \mathrm{~L} / \mathrm{s}$ ou $13.000 \mathrm{~m}^{3} / \mathrm{d}$, enquanto em uma cidade com 400.000 habitantes, praticamente toda com rede de esgoto instalada, deve-se produzir no mínimo $40.000 \mathrm{~m}^{3} / \mathrm{d}$, ou seja, somente $1 / 3$ do esgoto gerado é atualmente tratado, enquanto $2 / 3$ ou mais não recebem tratamento e são infiltrados ou descarregados no sistema de drenagem urbana que leva a água para o riacho Bodocongó e escoa para Acauã, praticamente sem tratamento.

(2) Atualmente, a ETE de Campina Grande já se encontra um pouco sobrecarregada: a concentração dos coliformes termotolerantes é da ordem de $2.10^{3}$ UFC/100 mL, sistematicamente acima de $10^{3}$. Ainda assim, a qualidade higiênica do efluente do sistema de tratamento é muito melhor do que a qualidade no corpo receptor, que é em torno de $10^{4}-10^{5} \mathrm{UFC} / 100 \mathrm{~mL}$ (MAGALHÃES et al., 2002). Naturalmente, se todo o esgoto gerado em Campina Grande fosse tratado na ETE, a qualidade da água no Riacho Bodocongó melhoraria.

(3) Na ETE, não há remoção de nutrientes, e o efluente do sistema de tratamento, junto com o esgoto não tratado, escoa via Riacho Bodocongó e do Rio Paraíba para o açude Acauã. No reservatório de Acauã, que possui volume máximo de 250 milhões de $\mathrm{m}^{3}$, há, portanto, a descarga dos nutrientes $\mathrm{N}$ e P em $10 \mathrm{gN}$ hab $^{-1} \mathrm{~d}^{-1}$ (ou $4000 \mathrm{kgN} . \mathrm{d}^{-1}$ ) e $1 \mathrm{gP} . \mathrm{hab}^{-1} \mathrm{~d}^{-1}$ (ou $400 \mathrm{kgP}^{-1}$ ). Assim, tem-se que no açude são descarregados diariamente no mínimo 16 mgN e 1,6 mgP por $\mathrm{m}^{3}$, o que causa eutrofização de uma água que se destina ao abastecimento de várias cidades da região do médio Paraíba. O resultado é que, apesar dos esforços do tratamento, a água tem fortes odor e sabor, causados pelas algas que crescem no açude.
(4) Em Campina Grande existe uma demanda reprimida de água para indústrias, que é uma das principais razões da falta de desenvolvimento do setor. Todavia, como o tratamento de esgoto na ETE não inclui remoção de nutrientes, o efluente não serve para uso como água de utilidades na indústria. Assim, a indústria, em vez de usar esgoto tratado, tem que competir com água de abastecimento público para atender às suas necessidades.

(5) Na região rural de Campina Grande há também a falta de disponibilidade de água para agricultura, o que limita o desenvolvimento nesse setor. A irrigação "informal” com água de qualidade higiênica inferior é usada em grande escala para produção de verduras, como tem sido demonstrado repetidamente em pesquisas da qualidade de verduras nas feiras de Campina Grande (BARROS et al., 1999; LIMA et al., 2005). É necessário que as autoridades competentes intervenham e que regulem o reúso de água após o tratamento adequado e sob supervisão de uma unidade de controle sanitário.

(6) A qualidade do efluente do sistema de tratamento hoje é razoável, mas isso se deve ao fato de que somente uma fração de aproximadamente $1 / 3$ da vazão de esgoto é tratada na ETE. Se toda a vazão fosse tratada, o efluente teria uma qualidade inferior. Assim, conclui-se que a capacidade de tratamento do sistema não é compatível com a vazão que devia ser tratada.

Em parte, os problemas podem ser atribuídos à decisão de construir na segunda etapa um sistema de lagoas de estabilização convencional. O sistema de lagoas de estabilização convencional é amplamente utilizado pelas companhias de água e esgotos no país: em torno de $50 \%$ dos esgotos do Brasil são tratados por esse tipo de sistema (IBGE, 2008). Todavia, esse sistema de tratamento apresenta várias desvantagens e 
hoje deve ser considerado como uma opção de tratamento obsoleto que não devia ser aplicada. As principais desvantagens são:

(1) Embora a ETE de Campina Grande seja grande, a capacidade de tratamento é insuficiente para tratar todo o esgoto gerado na cidade. A área das lagoas da segunda etapa (lagoas facultativas e de maturação) é de aproximadamente $240.000 \mathrm{~m}^{2}$ para uma população contribuinte de 400.000 habitantes, ou seja, 0,6 $\mathrm{m}^{2}$.hab ${ }^{-1}$, quando se sabe que geralmente se adota uma área de $3 \mathrm{~m}^{2} /$ hab para que haja remoção eficiente de material orgânico e coliformes termotolerantes. Mesmo considerando que as condições no Planalto da Borborema são favoráveis para uma alta taxa de decaimento das bactérias, a área das lagoas é claramente insuficiente para produzir uma boa qualidade higiênica, se todo o esgoto coletado fosse tratado.

(2) O sistema não remove nutrientes de forma eficiente, o que não somente inviabiliza a utilização do efluente na indústria mas também não evita a eutrofização do corpo receptor: o açude Acauã. A rigor, devia ser evitada a adoção de lagoas de estabilização, porque estas não conseguem atender à qualidade estabelecida em legislações brasileiras, sobretudo para os nutrientes.

(3) O biogás gerado se desprende para a atmosfera causando problemas de odor (gás sulfídrico), o que muito contribui para a impopularidade do sistema e causa emissão de gases de efeito estufa pela presença de metano, que é 21 vezes mais danoso que do dióxido de carbono.

\subsection{Desempenho atual do sistema de} tratamento com uma vazão de $13.000 \mathrm{~m}^{3} / \mathrm{d}$

O sistema atual de tratamento é composto por 6 lagoas, cada uma com um volume de aproximadamente $50.000 \mathrm{~m}^{3}$ (cada lagoa tem 4 ha e uma profundidade de 1,25 m), perfazendo um total de $300.000 \mathrm{~m}^{3}$. A área das lagoas (24 ha) é pequena para uma população de 400.000 habitantes: $240.000 / 400.000=0,6 \mathrm{~m}^{2} / \mathrm{hab}$, enquanto geralmente se adota um valor na faixa de $3 \mathrm{~m}^{2} /$ hab. Como atualmente somente $1 / 3$ do esgoto é tratado, a área por habitante seria de fato maior: por volta de $0,6 \mathrm{~m}^{2} / \mathrm{hab} * 3=1,8 \mathrm{~m}^{2} / \mathrm{hab}$, o que se aproxima do valor desejável. 0 tempo efetivo de permanência nas lagoas é $300.000 \mathrm{~m}^{3} / 13.000$ $\mathrm{m}^{3} / \mathrm{d}=23$ dias.

O sistema de tratamento tem como objetivo a remoção de material orgânico e dos patógenos. Quanto à eficiência de remoção de material orgânico, esta é boa, resultando em um efluente com DBO (60 mg/L), bem menor do que a exigida pela Resolução $n^{\circ}$ 430/2011 do Conama (BRASIL, 2011), que é de $120 \mathrm{mg} / \mathrm{L}$. A eficiência de remoção de Coliformes termotolerantes (CTT) é elevada, mas o efluente tem uma concentração média de CTT em torno 2.000, enquanto o limite da referida Resolução é de 1.000 UFC/100 por mL.

Pequenas modificações podem melhorar o desempenho do sistema atual na remoção dos CTT, como indica a Fig. 5. A configuração existente (02 módulos de 3 lagoas em série operando com fluxo contínuo (2a)) pode ser substituída por um sistema de 6 lagoas em série operadas com fluxo contínuo (2b) ou 6 lagoas operadas em regime de bateladas sequenciais (2c). 


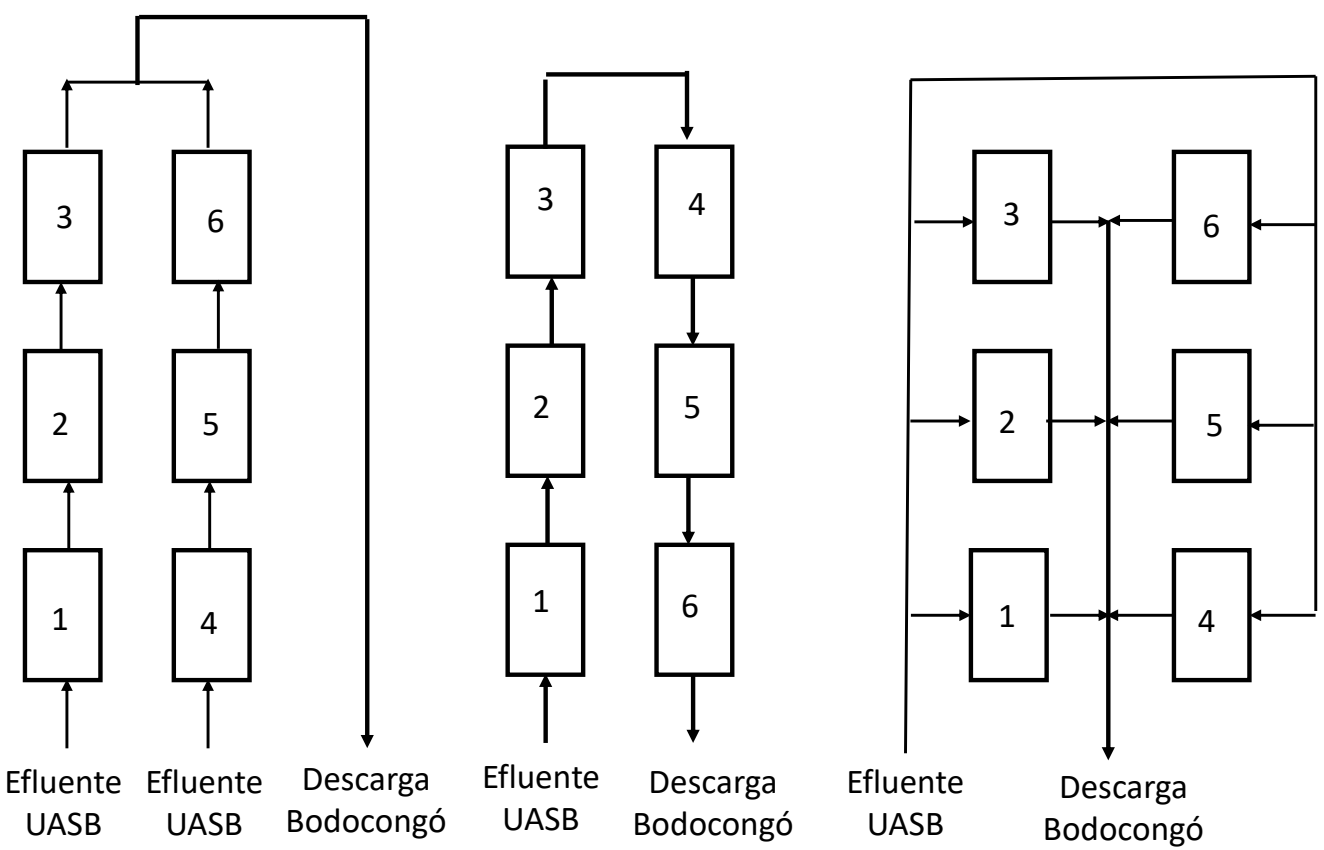

Figura 5 - Alternativas operacionais para as seis lagoas já construídas: (a) dois pares de três lagoas em série (esquerda); (b) uma série de seis lagoas (centro) ou (c) lagoa em regime de bateladas sequenciais (direita).

Pode-se mostrar que as três alternativas da Fig. 5 têm importante repercussão na remoção de CTT. De acordo com a teoria (MARAIS; SHAW, 1961), o decaimento é um processo de primeira ordem:

$\mathrm{dN} / \mathrm{dt}=-\mathrm{k}_{\mathrm{d}} \mathrm{N}$

A solução da equação básica depende da hidrodinâmica do reator onde o processo se desenvolve:

Reator de mistura completa:

$N_{e} / N_{i}=1 /\left(1+k_{d} R_{h}\right)$

Séria de reatores de mistura completa

$N_{e} / N_{i}=1 /\left(1+k_{d} R_{h} / M\right)$

Reator de bateladas sequenciais:

$N_{e} / N_{i}=\exp \left(-k_{d} R_{h}\right)$

Em que:

$\mathrm{N}_{\mathrm{e}}, \mathrm{N}_{\mathrm{i}}=$ Concentração de CTT na saída e na entrada do reator (UFC/100mL);

$k_{d}=$ Constante de decaimento bacteriano $\left(\mathrm{d}^{-1}\right)$;

$\mathrm{R}_{\mathrm{h}}=$ Tempo de permanência total (d);

$M=$ Número de reatores em série.
Batista et al. (2021) realizaram uma investigação para determinar o valor da constante de decaimento e a influência da profundidade da lagoa e da temperatura na fase líquida. $O$ resultado é uma expressão empírica que permite calcular o valor da constante de decaimento para qualquer situação:

$k_{d}=(1 / H) * 1,14^{* 1,07}(T-20)$

Em que:

$k_{d}=$ Constante de decaimento bacteriano $\left(d^{-1}\right)$;

$\mathrm{H}=$ Profundidade da lagoa $(\mathrm{m})$;

$\mathrm{T}=$ Temperatura do líquido $\left({ }^{\circ} \mathrm{C}\right)$.

No caso particular da ETE em Campina Grande, a constante de decaimento pode ser estimada como:

$k_{d}=1 / 1,25^{*} 1,14^{*} 1,07^{(25-20)}=1,27 d^{-1}$

Para a vazão atual de $13.000 \mathrm{~m}^{3} / \mathrm{d}$ e um volume das lagoas de $6 * 50.000 \mathrm{~m}^{3}=300.000 \mathrm{~m}^{3}$, o tempo de permanência é: 
$R_{h}=300.000 m^{3} / 13.000 m^{3} / d=23$ dias

As lagoas anaeróbias estão praticamente cheias de sólidos e devem ter uma contribuição limitada para o decaimento das bactérias. Assim, o decaimento se dá basicamente nas seis lagoas. Dessa forma, pode-se calcular a eficiência das lagoas em várias configurações:

(1) Atual: 02 módulos de 03 lagoas de fluxo contínuo (Fig. 5a):

$\mathrm{N}_{\mathrm{e}} / \mathrm{N}_{\mathrm{i}}=1 /\left(1+\mathrm{k}_{\mathrm{d}} \mathrm{R}_{\mathrm{h}} / \mathrm{M}\right)^{\mathrm{M}}=1 /(1+1,27 * 0,5 * 23 / 3)^{3}=$ $4,9 * 10^{-3}$

Supondo-se que no esgoto após o pré-tratamento a concentração de CTT seja $10^{7}$ UFC por $100 \mathrm{~mL}$, calcula-se um efluente de $4,9 * 10^{4}$ UFC/ $100 \mathrm{~mL}$. Conclui-se que a concentração encontrada de $2,0 * 10^{3} \mathrm{UFC} / 100 \mathrm{~mL}$ é menor que o valor calculado, possivelmente por uma remoção nas lagoas anaeróbias.

(2) Com modificação operacional: 1 módulo de 06 lagoas de fluxo contínuo (Fig. 5b):

$N_{e} / N_{i}=1 /(1+1,27 * 23 / 6)^{6}=2,4 * 10^{-5}$

Neste caso, supondo novamente $\mathrm{N}^{\mathrm{i}}=10^{7} \mathrm{UFC} / 100 \mathrm{~mL}$ no afluente, a concentração no efluente seria: $\mathrm{Ne}=2,4 * 10^{2} \mathrm{UFC} / 100 \mathrm{~mL}$, portanto bem menor que o limite de $10^{3} \mathrm{UFC} / 100 \mathrm{~mL}$. Conclui-se que a atu- al configuração de 2 módulo com 3 lagoas, cada (Fig. 5a) pode ser substituída com grande vantagem pela configuração de 6 lagoas em série (Fig. 5b).

(3) Com modificação na hidrodinâmica: 6 lagoas operando em regime de bateladas sequenciais: (Fig. 5c).

Nesse caso, deve-se levar em consideração que é necessário um tempo considerável para encher uma lagoa de $50.000 \mathrm{~m}^{3}$. Admitindose que a vazão de recalque de efluente da lagoa de transbordo seja igual à vazão de esgoto $\left(13.000 \mathrm{~m}^{3} / \mathrm{d}\right)$, o tempo para encher uma lagoa seria de $50.000 \mathrm{~m}^{3} / 13.000 \mathrm{~m}^{3} \cdot \mathrm{d}^{-1}=3,8$ dias, de modo que para o decaimento sobraria um tempo de $23-3,8=19,2 \mathrm{~d}$. Para o decaimento exponencial, calcula-se uma eficiência de:

$N_{e} / N_{i}=\exp \left(-k_{d} R_{h}\right)=\exp (-1,27 * 19,2)=2,1 * 10^{-11}$

Conclui-se que a remoção dos CTT em lagoas de bateladas sequenciais seria completa.

Pode-se repetir os cálculos acima para o cenário em que todo o esgoto de Campina Grande $\left(40.000 \mathrm{~m}^{3} / \mathrm{d}\right)$ seria tratado nas lagoas. Na Tabela 2 podem ser observados os resultados para as três configurações apresentadas na Fig. 5 para $13.000 \mathrm{~m}^{3} \cdot \mathrm{d}^{-1}$ (vazão atual) e $40.000 \mathrm{~m}^{3} \cdot \mathrm{d}^{-1}$ (vazão mínima para atender ao esgoto produzido na área urbana).

Tabela 2 - Valores da eficiência e da concentração residual dos coliformes termotolerantes para diferentes vazões e configurações das lagoas.

\begin{tabular}{|c|c|c|c|c|c|c|}
\hline Vazão & \multicolumn{3}{|c|}{$13.000 \mathrm{~m}^{3} / \mathrm{d}$} & \multicolumn{3}{|c|}{$40.000 \mathrm{~m}^{3} / \mathrm{d}$} \\
\hline Configuração & $\begin{array}{c}\text { 2*3 lagoas fluxo } \\
\text { contínuo } \\
\text { Fig. } 5 a\end{array}$ & $\begin{array}{c}6 \text { lagoas em série } \\
\text { fluxo cont. } \\
\text { Fig. } 5 b\end{array}$ & $\begin{array}{c}6 \text { lagoas bateladas } \\
\text { sequenciais } \\
\text { Fig. } 5 c\end{array}$ & $\begin{array}{c}\text { 2*3 lagoas fluxo } \\
\text { contínuo } \\
\text { Fig. } 5 a\end{array}$ & $\begin{array}{c}6 \text { lagoas em série } \\
\text { fluxo cont. } \\
\text { Fig. } 5 b\end{array}$ & $\begin{array}{c}6 \text { lagoas bateladas } \\
\text { sequenciais } \\
\text { Fig. } 5 c\end{array}$ \\
\hline $\mathrm{N}_{\mathrm{e}} / \mathrm{N}_{\mathrm{i}}$ & $4,9 * 10^{-3}$ & $2,4 * 10^{-5}$ & $2,1^{*} 10^{-11}$ & $5,8^{*} 10^{-2}$ & $3,3 * 10^{-3}$ & $3,6 * 10^{-4}$ \\
\hline$N_{e}\left(N_{i}=107\right)$ & $4,9 * 10^{4}$ & $2,4^{*} 10^{2}$ & $2,1 * 10^{-4}$ & $5,8 * 10^{5}$ & $3,3 * 10^{4}$ & $3,6 * 10^{3}$ \\
\hline
\end{tabular}


Os cálculos indicam que para a vazão atual a concentração residual dos CTT está acima do limite máximo permitido ( $10^{3}$ UFC por $100 \mathrm{~mL}$ ) para a configuração atualmente utilizada ( 2 módulos de 3 lagoas em série e fluxo contínuo); já nas duas outras configurações propostas, o efluente apresentaria uma qualidade higiênica satisfatória. Por outro lado, caso toda a vazão de esgoto produzida fosse tratada, nenhuma configuração produziria um efluente de qualidade satisfatória, ainda que o sistema com bateladas sequenciais se aproximasse $\left(\mathrm{N}_{e}=3,6 * 10^{3}\right.$ UFC por $\left.100 \mathrm{~mL}\right)$.

\section{MODIFICAÇÕES PROPOSTAS}

Os pontos fracos do atual sistema de tratamento em Campina Grande são:

(1) A capacidade de tratamento da ETE é pequena para a população servida;

(2) O sistema não remove nutrientes;

(3) A remoção de CTT é ineficiente, mas pode ser melhorada ao adotar a configuração da Fig. 5b ou 5 c.

Os problemas da ETE podem ser resolvidos em grande parte ao se adotar um sistema composto de um reator UASB e lagoas de polimento em regime de bateladas sequenciais (LPBS). Essas duas modificações podem radicalmente mudar a capacidade de tratamento da ETE e a qualidade do efluente do sistema de tratamento. O sistema modificado de tratamento de esgoto aproveitaria integralmente a infraestrutura existente e seria capaz de tratar todo o esgoto de Campina Grande, produzindo um efluente não somente capaz de evitar a eutrofização de Acauã, mas também produziria água com qualidade que permitiria o reúso na indústria ou na agricultura. $A$ Fig. 6 é uma representação esquemática das modificações que se propõe. Torna-se necessário construir algumas estruturas adicionais:
(1) Para processar o lodo de excesso do reator UASB, precisa-se de um conjunto de leitos de secagem com área estimada de $6.400 \mathrm{~m}^{2}$, que está disponível no terreno da ETE.

(2) Para processar a água a ser fornecida às indústrias, faz-se necessário aplicar a clarificação, além da digestão da suspensão de algas depois da clarificação.

(3) O aproveitamento do biogás para geração de energia pode ser aplicado (potência de $480 \mathrm{~kW}$ ), mas depende da viabilidade econômica. Se não houver viabilidade econômica, o biogás pode ser simplesmente queimado num flare.

A viabilidade de remoção de nutrientes com o sistema UASB-LPBS se deve à combinação de dois fatores:

(1) Devido ao tratamento anaeróbio eficiente no reator UASB, o efluente apresenta boa transparência (remoção dos sólidos suspensos e coloides), aumentando a taxa de fotossíntese nas lagoas, além de uma baixa demanda de oxigênio (baixa concentração de material orgânico residual). Como resultado, haverá produção de oxigênio e consumo de dióxido de carbono na LPBS, o que resulta num aumento do $\mathrm{pH}$.

(2) Os processos biológicos que se desenvolvem na LPBS são mais rápidos do que numa lagoa de polimento de fluxo contínuo (LPFC), que são invariavelmente aplicadas. Notadamente, o aumento do $\mathrm{pH}$ numa LPBS é mais rápido e maior do que numa LPFC.

Pesquisa desenvolvida por Albuquerque et al. (2021) mostrou que, por ser uma lagoa de bateladas sequenciais (LPBS), a remoção de material orgânico residual e de organismos patogênicos é mais rápida do que em $L P F C$ e, portanto, pode ter uma área menor para a mesma eficiência. A remoção de DBO e de CTT na LPBS é rápida porque não há necessidade de aumento do $\mathrm{pH}$. 
O mecanismo de remoção de nitrogênio em LPBS é a dessorção da amônia. Para o gás se desprender a uma taxa elevada, é necessário que o $\mathrm{pH}$ alcance um valor de 8,5 a 9 . Por outro lado, a remoção de fósforo se dá pela precipitação de hidroxiapatita de cálcio, $\mathrm{C}_{10}(\mathrm{OH})_{2}\left(\mathrm{PO}_{4}\right)_{6}$, quando o
$\mathrm{pH}$ atinge um valor de 9,7. Esse valor é estabelecido rapidamente em LPBS rasa.

Conclui-se que a LPBS pode ser usada para meIhorar a qualidade do efluente final em quatro aspectos: remoção de material orgânico, de coliformes termotolerantes, de nitrogênio e de fósforo.

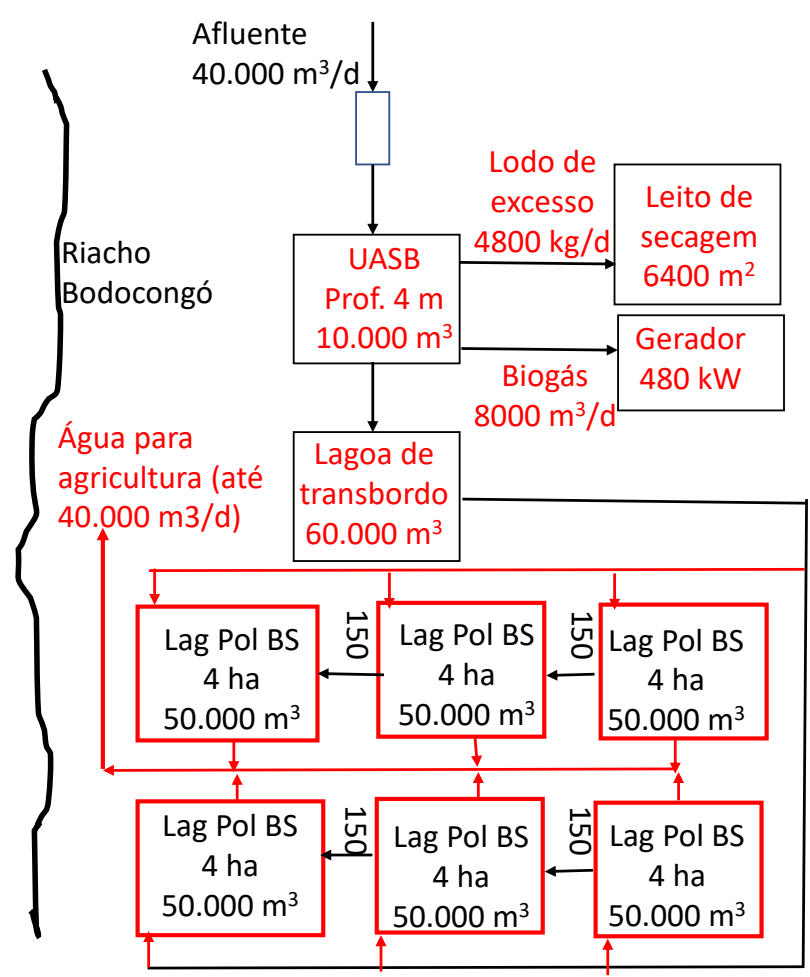

Figura 6 - Representação esquemática das modificações propostas para a ETE de Campina Grande (em vermelho).

Todavia, o tempo necessário para efetuar a remoção dos quatro componentes indesejáveis é diferente, como é diferente a área necessária. A Fig. 7 mostra o resultado de pesquisas desenvolvidas pelo nosso grupo de trabalho, onde foi obtido um valor de área necessária para as LPBS no verão e no inverno para as condições climatológicas de Campina Grande. Essa figura mostra também que a profundidade ótima da LPBS é em torno de $0,5 \mathrm{~m}$. A Tabela 3 mostra a área per capita para a profundidade ótima de 0,5 m, muito menor que a profundidade de uma lagoa convencional (1 a 1,5 m). A Fig. 7 e a Tabela 3 permitem tecer os seguintes comentários:
(1) A área necessária para a remoção da DBO é a menor para os quatro constituintes indesejáveis a serem removidos na LPBS;

(2) A área para remoção dos Coliformes termotolerantes é determinante para LPBS quando o efluente for para fins de reúso agrícola;

(3) A área para remoção da DBO e dos CTT é praticamente independente da profundidade;

(4) A área para remoção de Nitrogênio é bem maior do que para remoção dos CTT; 
(5) A área para remoção de Fósforo é quase o dobro da área necessária para remoção de nitrogênio;

(6) A área da combinação UASB-LPBS é sempre menor do que a área necessária em lagoas de estabilização convencionais, que é em torno de $3 \mathrm{~m}^{2} /$ hab;

(7) A profundidade ótima das LPBS é em torno de $0,5 \mathrm{~m}$, o que pode reduzir os custos de construção consideravelmente.
Lagoas no verão paraibano

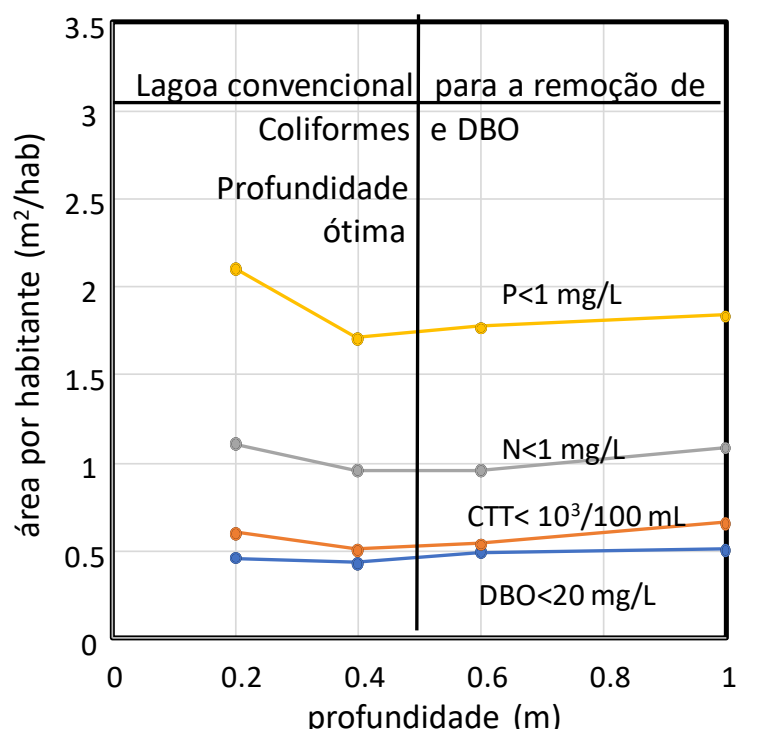

Lagoas no inverno paraibano

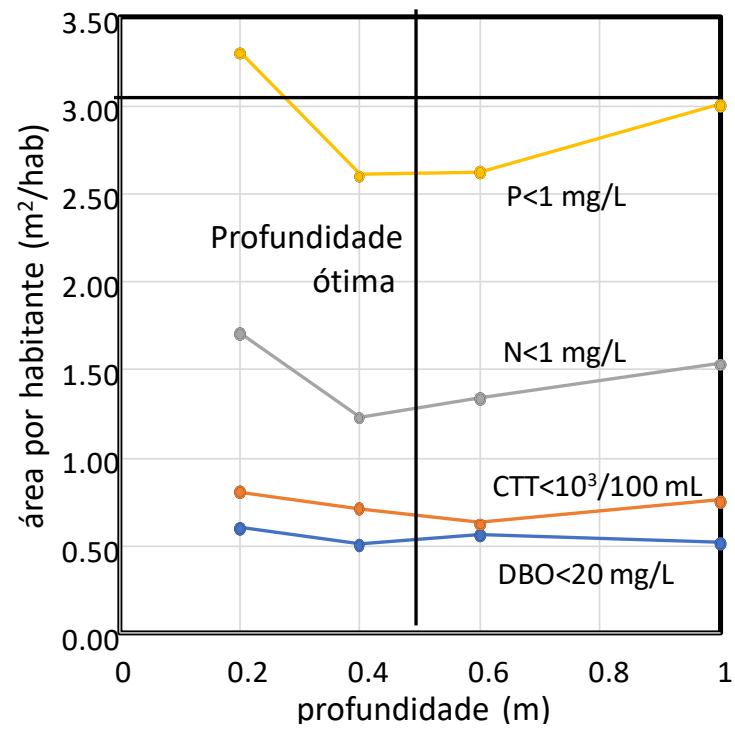

Figura 7 - Área per capita das LPBS em função da profundidade para remoção da DBO, dos coliformes termotolerantes, de nitrogênio amoniacal e de fosfato para uma contribuição per capita de $100 \mathrm{~L} \cdot \mathrm{hab}^{-1} \cdot \mathrm{d}^{-1}$ para as condições de verão e de inverno em Campina Grande-PB.

Tabela 3 - Área per capita necessária $\left(\mathrm{m}^{2}\right.$.hab $\left.{ }^{-1}\right)$ para a remoção de DBO, CTT, Nitrogênio e Fósforo em LPBS com profundidade de 0,5 m para as condições de clima de Campina Grande no verão e no inverno.

\begin{tabular}{|c|c|c|c|c|}
\hline Condição climática & $\begin{array}{c}\text { DBO } \\
\text { (<20 mg/L) }\end{array}$ & $\begin{array}{c}\text { CTT } \\
(99,99 \%)\end{array}$ & $\stackrel{\mathrm{N}}{\mathrm{NgN} / \mathrm{L})}$ & $\underset{(<1 \mathrm{mgP} / \mathrm{L})}{P}$ \\
\hline Verão & 0,5 & 0,6 & 0,9 & 1,8 \\
\hline Inverno & 0,6 & 0,7 & 1,3 & 2,6 \\
\hline
\end{tabular}

\subsection{Dimensionamento das unidades de tratamento a serem construídas}

\section{(1) Reator UASB}

Para a vazão prevista de $40.000 \mathrm{~m}^{3} \cdot \mathrm{d}^{-1} \mathrm{e}$ um tempo de permanência de $6 \mathrm{~h}$, o volume do UASB seria $10.000 \mathrm{~m}^{3}$, por exemplo, 5 unidades de $2000 \mathrm{~m}^{3}$. Essas unidades seriam construídas no fundo da atual lagoa anaeróbia, eventualmente rebaixado para permitir a operação do UASB por gravidade com uma profundidade útil de $4 \mathrm{~m}$. Assim, a área de cada unidade seria de 2000/4 =500 $\mathrm{m}^{2}$, tendo-se, por exemplo, 5 unidades com comprimento de $20 \mathrm{~m}$ e largura de $25 \mathrm{~m}$ da maneira indicada na Fig. 8. 0 restante da área da lagoa seria utilizada para a sedimentação dos sólidos eventualmente descarregados do UASB. A produção de lodo seria 0,15 kgSST/kgDQQO ou $0,15 * 32000=4800 \mathrm{kgSST}$, que seriam recalcados 
para os leitos de secagem, visando à produção de fertilizante orgânico. $O$ efluente dessa unidade iria por gravidade para a segunda lagoa anaeróbia, que também teria a função de lagoa de transbordo.

\section{(2) Lagoa de transbordo}

A segunda lagoa anaeróbia pode ser usada como uma lagoa de transbordo, de onde se recalca o efluente do UASB decantado para as lagoas de polimento. O volume da lagoa anaeróbia $\left(60.000 \mathrm{~m}^{3}\right)$ é suficiente para recalcar uma batelada com capacidade para encher as lagoas de polimento, que terá um volume máximo de $50.000 \mathrm{~m}^{3}$ (vide item 5).

\section{(3) Leitos de secagem de lodo}

Quanto à secagem de lodo, é necessário saber a produtividade dos leitos de secagem, que é a massa de lodo que pode ser seca por dia e por unidade de área. Em pesquisas anteriores, estabeleceu-se que para as condições climáticas de Campina Grande um lodo seco com 30\% de umidade pode ser produzido com uma produtividade de $0,75 \mathrm{kgSST} \cdot \mathrm{m}^{-2} \cdot \mathrm{d}^{-1}$. Portanto, para uma produção de $4.800 \mathrm{kgSST} . \mathrm{d}^{-1}$ necessitar-se-ia de uma área de $4800 \mathrm{kgSST} . \mathrm{d}^{-1} / 0,75 \mathrm{kgSSS} \cdot \mathrm{m}^{-2} \cdot \mathrm{d}^{-1}=6400 \mathrm{~m}^{2}$, que estaria disponível na ETE.

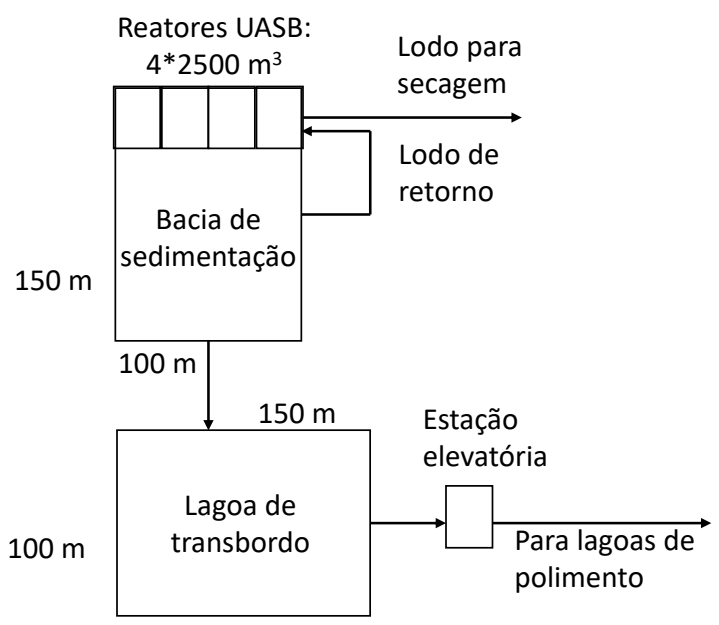

Figura 8 - Pré-tratamento anaeróbio em reator UASB e lagoa de transbordo.

\section{(4) Unidade de geração de energia elétrica}

Para estimar a produção de metano, usa-se o seguinte raciocínio: a lagoa de fluxo ascendente, por ter um tempo de permanência longo, terá uma alta eficiência de remoção de material orgânico: estima-se que pelo menos $75 \%$ da DQO será removida após a sedimentação de sólidos na lagoa de transbordo. Assim, para uma vazão de $40.000 \mathrm{~m}^{3} / \mathrm{d}$ e uma concentração de DQQO no afluente de $0,8 \mathrm{~g} / \mathrm{L}$, a carga orgânica é estimada em $40.000 \mathrm{~m}^{3} / \mathrm{d} * 0,8 \mathrm{~g} / \mathrm{L}=32.000 \mathrm{kgDOO} / \mathrm{d}$, tendo-se até $25 \%$ no efluente com uma concentração de 0,2 g/L. A produção de lodo de excesso seria aproximadamente $15 \%$ da carga orgânica, $32.000 \mathrm{kgDQO} / \mathrm{d} * 0,15=4.800 \mathrm{kgDQOO} / \mathrm{d}$, resultando numa massa de lodo volátil de $4.800 \mathrm{kgDQO} . \mathrm{d}^{-1} / 1,5=3200 \mathrm{kgSVS} / \mathrm{d}$. Com uma fração volátil do lodo de 2/3 (VAN HAANDEL; VAN DER LUBBE, 2019), espera-se uma produção de lodo de $1,5 * 3.200 \mathrm{kgSVS} / \mathrm{d}=4.800 \mathrm{kgSST} / \mathrm{d}$.

A produção de metano pode ser estimada, sabendo-se que a digestão de $1 \mathrm{~kg}$ de DQQO gera $1 / 4 \mathrm{~kg}$ de metano. A massa de DQO digerida será igual à carga orgânica aplicada menos a carga orgânica para a produção de lodo (4.800 kgDQO/d) menos a carga orgânica no efluente $(0,25 * 32.000=8.000 \mathrm{kgDOO} / \mathrm{d})$. Portanto, a produção de metano é: $(32.000 \mathrm{kgDOO} / \mathrm{d}$ $8000 \mathrm{kgDQO} / \mathrm{d}-4800 \mathrm{kgDQO} / \mathrm{d}) / 4=4.800 \mathrm{kgCH}_{4}$. Dessa quantidade, em torno de $25 \%$ permanecerão dissolvidos no efluente e outros $25 \%$ serão perdidos como fugas, havendo uma quantidade para produção de energia elétrica de $2400 \mathrm{kgCH}_{4} / \mathrm{d}$. Sabendo que a eficiência de conversão de metano em energia elétrica é de 0,2 kW por $\mathrm{kgCH}_{4} \cdot \mathrm{d}^{-1}$, aproximadamente, o potencial de produção de energia elétrica de $0,2 * 2.400=480 \mathrm{~kW}$. Uma análise econômica deve estabelecer se é conveniente realizar o potencial ou queimar 0 biogás gerado. 
(5) Transformação das lagoas de polimento de fluxo contínuo em lagoa de batelada sequenciais

Para alimentar as lagoas de polimento de bateladas sequenciais com efluente do reator UASB que tem fluxo contínuo existem em princípio duas possibilidades, como indicado na Fig. 9: As lagoas de polimento podem ser alimentadas sequencialmente com esgoto digerido, como indica a Fig. 9 à esquerda ou o efluente do reator UASB pode ser recolhido num lagoa de transbordo que então alimenta as lagoas de polimento. A lagoa de transbordo, além de ser um taque de equalização, funciona também como decantador do lodo que é descarregado do UASB e para iniciar a fotossíntese.

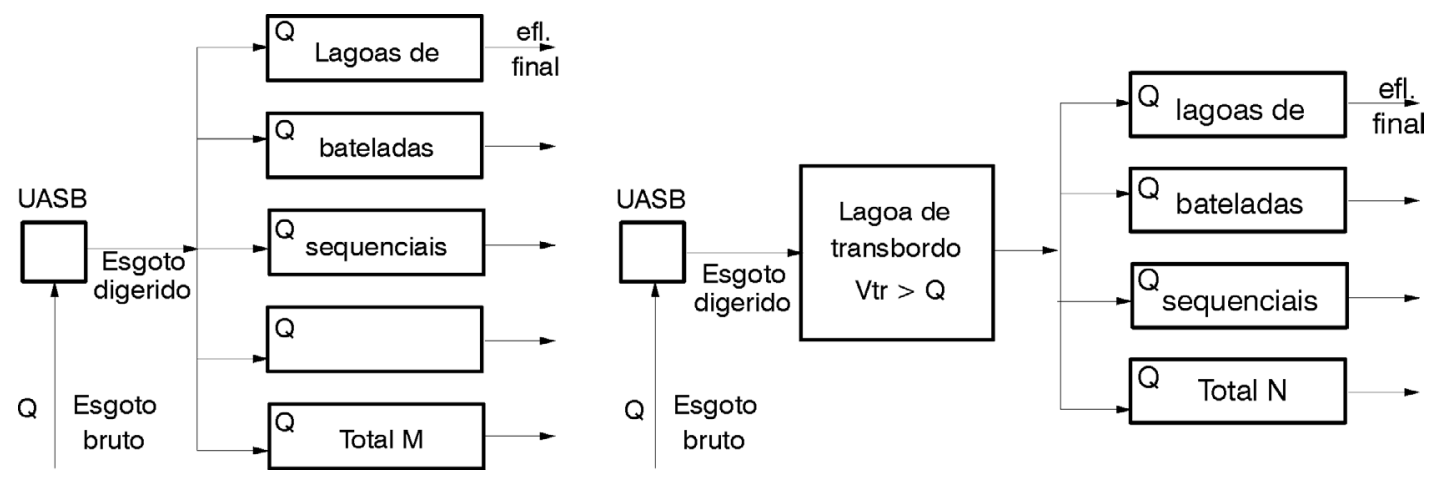

Figura 9 - Esquema da disposição e operação de lagoas de polimento alimentadas em bateladas sequenciais sem (7a, esquerda) e com (7b, direita) uma lagoa intermediária de transbordo.

\section{(6) Produção de água para reúso}

Pode-se estimar a área necessária para duas situações em particular: (1) produção de água para reúso agrícola; e (2) produção de água para indústrias com remoção de nitrogênio por dessorção e remoção de fósforo por clarificação.

\section{(a) Produção de água para reúso agrícola}

Água de reúso agrícola requer $0,7 \mathrm{~m}^{2} \cdot \mathrm{hab}^{-1}$, ou seja, $0,7 \mathrm{~m}^{2}$.hab ${ }^{-1 *} 400.000 \mathrm{hab}=280.000 \mathrm{~m}^{2}$ ou 28 ha para Campina Grande. 0 que se tem disponível é $6 * 4$ ha $=24$ ha, ou seja, a área atualmente disponível é um pouco menor do que a área necessária para produzir um efluente com menos que 103 UFC por 100 mL. A remoção no UASB e na lagoa de transbordo será suficiente para dar a pequena eficiência a mais do sistema, para produzir um efluente final com qualidade higiênica para irrigação sem restrições. Assim, conclui-se que as lagoas já construídas têm área suficiente para produzir um efluente com qualidade higiênica que permitirá seu uso na agricultura para qualquer cultivo, desde que se transformem as lagoas de polimento de fluxo contínuo em lagoas de polimento de bateladas sequenciais.

\section{(b) Produção de água para indústria}

Água de reúso na indústria requer remoção de nutrientes e de sólidos em suspensão. Como os sólidos em suspensão (algas) precisam ser removidos, aplica-se clarificação usando-se coagulantes como PAC (Policloreto de alumínio), e nesse processo há remoção química de fósforo. Portanto, a área tem de ser suficiente para a remoção de nitrogênio, que é $1,3 \mathrm{~m}^{2}$./hab-1 ou $1,3 \mathrm{~m}^{2} . / \mathrm{hab}^{-1} * 400.000 \mathrm{hab}=520.000 \mathrm{~m}^{2}$ ou 52 hectares (Tabela 3), bem mais que a área disponível. Todavia, só se produziria para a indústria 
a quantidade que as atividades industriais efetivamente demandam. Em Campina Grande, a FIEP (Federação de Indústrias do Estado da Paraíba) estima que o consumo atual de água pelas indústrias seja em torno de $10.000 \mathrm{~m}^{3} / \mathrm{d}$, equivalente à produção de esgoto de 100.000 habitantes, ou seja, $1 / 4$ do esgoto seria transformado em água para indústria. Para produzir essa vazão, a área necessária seria uma área de $1,3 \mathrm{~m}^{2} /$ hab*100.000 hab = $130.000 \mathrm{~m}^{2}$ ou 13 ha, ou seja, aproximadamente metade da área disponível de 24 ha. Todavia, não seria possível produzir água para indústria $\left(10.000 \mathrm{~m}^{3} / \mathrm{d}\right)$ e água para agricultura $\left(30.000 \mathrm{~m}^{3} / \mathrm{d}\right)$ na área atualmente disponível. Uma solução poderia ser a construção de mais três lagoas de polimento para a produção de água para reúso industrial, como mostra a Fig. 10. Nesse caso, as seis lagoas existentes seriam suficientes para produzir água para agricultura dos $30.000 \mathrm{~m}^{3}$ restantes.

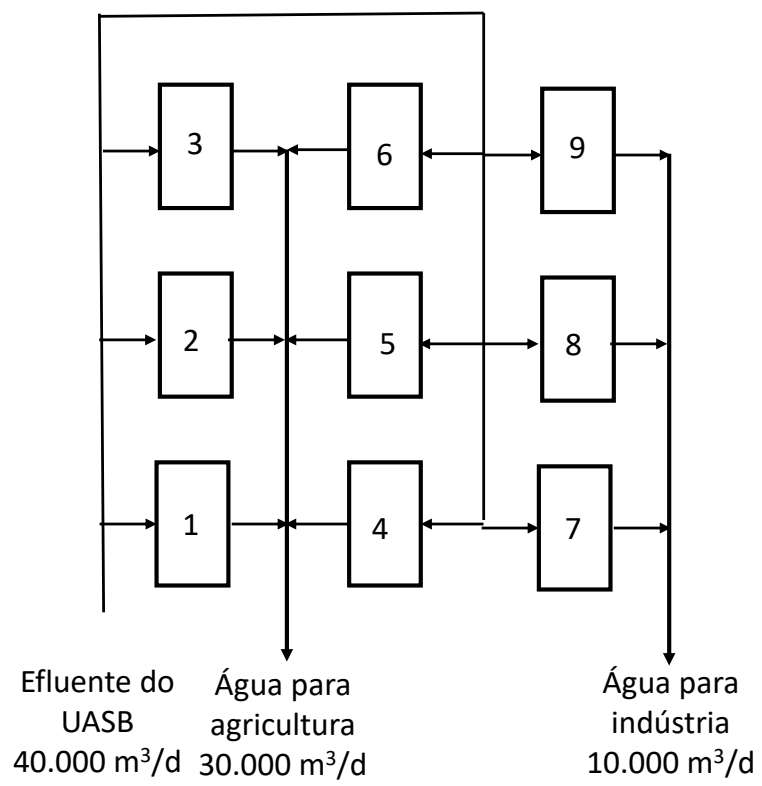

Figura 10 - Configuração das lagoas para a produção de $30.000 \mathrm{~m}^{3} / \mathrm{d}$ de água para agricultura e $10.000 \mathrm{~m}^{3} / \mathrm{d}$ de água para reúso industrial.

As lagoas a serem construídas não seriam iguais às lagoas já existentes, uma vez que a profundi- dade das lagoas para remoção de nitrogênio é de somente $0,5 \mathrm{~m}$, enquanto as lagoas existentes têm uma profundidade máxima de $1,5 \mathrm{~m}$. Também não seria necessário que o fundo das lagoas tivesse que ser alinhado ao solo, uma vez que todas as LPBS operam independentemente.

É interessante observar que o reúso de esgoto para indústrias, do ponto de vista econômico, é bem mais favorável do que o reúso na agricultura. Não somente as indústrias podem pagar um preço mais alto, mas também o valor da água nas indústrias é muito mais alto do que na agricultura. Assim, o custo adicional de preparar o efluente final do sistema de tratamento para utilização na indústria acaba sendo compensado pelo valor mais elevado do produto final.

\section{CONCLUSÕES}

(1) A capacidade de tratamento da ETE de Campina Grande é pequena para a vazão estimada de esgoto de $40.000 \mathrm{~m}^{3} / \mathrm{d}$. Nas condições atuais, o sistema recebe em torno de $13.000 \mathrm{~m}^{3} / \mathrm{d}$, ou seja, $1 / 3$ da produção de esgoto, e está com dificuldades de produzir um efluente com qualidade, especialmente em termos de remoção de bactérias coliformes, compatível com os padrões de lançamento brasileiros. É previsível que o sistema de tratamento seja insuficiente para tratar todo o esgoto de Campina Grande.

(2) A capacidade de tratamento da ETE de Campina Grande é baixa, porque utiliza a configuração de um sistema convencional de lagoas de estabilização, sistema este que poderia ser substituído por alternativas que fossem ao mesmo tempo simplificadas e mais eficientes.

(3) Se o sistema fosse modificado de acordo com as sugestões apresentadas neste artigo, a capacidade de tratamento poderia ser aumentada para $40.000 \mathrm{~m}^{3} / \mathrm{d}$, se o tratamento não inclu- 
ísse remoção de nitrogênio. Nessas condições, todo o efluente teria que ser usado para irrigação, evitando-se assim a eutrofização do corpo receptor e de outros corpos d'água a jusante do lançamento, como é o caso do açude Acauã. As modificações poderiam ser implementadas com custos relativamente baixos porque toda a infraestrutura existente seria aproveitada.

(4) No sistema modificado haveria pré-tratamento anaeróbio mais eficiente, pela substituição da lagoa anaeróbia convencional por um conjunto de reatores UASB, o que aumentaria significativamente a eficiência de remoção da DBO.

(5) A segunda modificação importante seria a maneira de operar as lagoas do pós-tratamento, que teria um regime de bateladas sequenciais em vez da operação atual com fluxo contínuo. A operação com bateladas sequenciais aumenta a capacidade de tratamento e abre a possibilidade de remoção de nutrientes.

(6) Com as modificações instaladas, a capacidade de tratamento aumentaria dos seus atuais $13.000 \mathrm{~m}^{3} / \mathrm{d}$ para $40.000 \mathrm{~m}^{3} / \mathrm{d}$ se o objetivo fosse produção de água para reúso agrícola ou de $20.000 \mathrm{~m}^{3} / \mathrm{d}$ para produção de água para reúso industrial. Para a demanda estimada de $10.000 \mathrm{~m}^{3} / \mathrm{d}$ de água para indústrias $\mathrm{e}$ $30.000 \mathrm{~m}^{3} / \mathrm{d}$ para agricultura, haveria necessidade de aumentar a área das lagoas de polimento: três novas lagoas teriam de ser construídas.

(7) Além do reúso produtivo do efluente da ETE, as modificações abrem a possibilidade de produção de biogás e utilização de lodo. A partir do biogás poderia ser gerada uma potência de $480 \mathrm{~kW}$. A produção de lodo (4800 kgSTS/d) poderia ser usada como fertilizante orgânico na agricultura.

\section{AGRADECIMENTOS}

Os autores agradecem ao Conselho Nacional de Desenvolvimento Científico e Tecnológico (CNPq) pelo incentivo financeiro às pesquisas.

\section{CONTRIBUIÇÃO DOS AUTORES}

Todos os autores contribuíram de forma igualitária.

\section{REFERÊNCIAS}

AGÊNCIA EXECUTIVA DE GESTÃO DAS ÁGUAS DO ESTADO DA PARAÍBA - AESA. Monitoramento: Últimos volumes informados dos Açudes. Disponível em: http://www.aesa.pb.gov.br/aesa-website/monitoramento/. Acesso em 25 set. 2020.

AGÊNCIA EXECUTIVA DE GESTÃO DAS ÁGUAS DO ESTADO DA PARAÍBA - AESA. Plano Estadual de Recursos Hídricos do Estado da Paraíba. Relatório Final Consolidado. 2006. Disponível em: http://www.aesa.pb.gov.br/aesa-website/wp-content/uploads/2016/11/PE_01.pdf. Acesso em 25 set de 2020.

AGÊNCIA NACIONAL DE ÁGUAS - ANA. Boletim de Acompanhamento da Alocação- Agosto/2020: Sistema hídrico Epitácio Pessoa. Disponível em: https://www.ana.gov.br/regulacao/resolucoes-e-normativos/regras-especiais-de-uso-da-agua/alocacao-de-agua/pb. Acesso em 25 set. 2020.

ALBUQUURQUUE, M. S.; SANTOS, S. L.; VAN HAANDEL, A. Influência do regime hidrodinâmico sobre o desempenho de lagoas de polimento. Revista DAE: Edição especial, São Paulo, n. 229, março 2021.

BARROS, A. J. M. et al. Avaliação sanitária de hortaliças no agreste e brejo paraibanos. Revista Brasileira de Engenharia Agrícola e Ambiental, v. 3, n. 3, p. 355-360, 1999. https://doi. org/10.1590/1807-1929/agriambi.v3n3p355-360

BRASIL. Conselho Nacional do Meio Ambiente. Resolução n 430 , de 13 de maio de 2011. Dispõe sobre as condições e padrões de lançamento de efluentes, complementa e altera a Resolução $n^{\circ}$ 357, de 17 de março de 2005, do Conselho Nacional do Meio Ambiente - CONAMA.

BATISTA, M. M.; LAMBAIS, G. R.; SANTOS, S. L.; VAN HAANDEL, A. Decaimento bacteriano em lagoas de polimento tratando efluente de reator UASB. Revista DAE: Edição especial, São Paulo, n. 229, março 2021.

CAMPINA GRANDE. Secretaria De Planejamento. Diagnóstico da Situação dos Serviços de Saneamento Básico. In: Plano Municipal de Saneamento Básico do Município de Campina Grande. Campina Grande: UFCG, 2015.

GOMES, E. F. Perdas de vazão e seus efeitos na operação do sistema de esgotamento sanitário de Campina Grande-PB. Disser- 
tação (Mestrado em Engenharia Civil e Ambiental), Universidade Federal de Campina Grande, Campina Grande, PB, 2013. 82p.

INSTITUTO BRASILEIRO DE GEOGRAFIA E ESTATÍSTICA - IBGE. IBGE Cidades. Disponível em: https://cidades.ibge.gov.br/brasil/ pb/campina-grande/panorama. Acesso em 25 set. 2020.

INSTITUTO BRASILEIRO DE GEOGRAFIA E ESTATíSTICA - IBGE. Pesquisa Nacional de Saneamento Básico - 2008, 2010. Disponível em: http://www.ibge.gov.br. Acesso em: 20 fev. 2020.

LIMA, S. M. S. et al. Qualidade sanitária e produção de alface irrigada com esgoto doméstico tratado. Revista Brasileira de Engenharia Agrícola e Ambiental, v. 9, n. Suplemento, p. 21-25, 2005.

LINS, R.P.M. Estrutura e Dinâmica da Comunidade Fitoplanctônica em um Reservatório Eutrófico do Trópico Semiárido Brasileiro Campina Grande - PB. Tese (Doutorado em Recursos Naturais) - CTRN. Universidade Federal de Campina Grande, Campina Grande, PB, 2011. 118p.

LINS, R.P.M. Limnologia da Barragem de Acauã e codeterminantes socioeconômicos do seu entorno: uma nova interação do limnológo com sua unidade de estudo. Dissertação (Mestrado em Desenvolvimento e Meio Ambiente), Universidade Federal da Paraíba - Universidade Estadual da Paraíba, João Pessoa, PB, 2006. 133p.

MAGALHÃES, N. F; CEBALLOS; B. S. O. DE; NUNES, A. B. DE A.; GHEYI, H.R.; KONIG, A. Principais impactos nas margens do Baixo Rio Bodocongó - PB, decorrentes da irrigação com águas poluídas com esgoto. Revista Brasileira de Engenharia Agrícola e Ambiental, v. 6, n. 1, p. 128-135, 2002. ISSN 1415-4366

MARAIS, G.V.R.; SHAW V.A. A rational theory for the design of sewage stabilizarion ponds in Central and South Africa. Trans. S. Afr. Instn. Civ. Engrs, v. 3, 1964.

SISTEMA NACIONAL DE INFORMAÇÕES SOBRE SANEAMENTO - SNIS. Série Histórica. Brasília: Ministério do Desenvolvimento Regional. Disponível em: http://app4.mdr.gov.br/serieHistorica/. Acesso em: 25 set. 2020.

VAN HAANDEL, A.C.; VAN DER LUBBE, J. Anaerobic sewage digestion: Theory and applications. International Water Association Londres RU, 2019. 